Case Report

\title{
A Rare Presentation of In Situ Mantle Cell Lymphoma and Follicular Lymphoma: A Case Report and Review of the Literature
}

\author{
Josephine Taverna, ${ }^{1}$ Anju Nair, ${ }^{2}$ Seongseok Yun, ${ }^{2}$ Spencer Paulson, ${ }^{3}$ Jonathan H. Schatz, ${ }^{1}$ \\ Daniel Persky, ${ }^{1}$ Deborah Fuchs, ${ }^{3}$ and Soham Puvvada ${ }^{1}$ \\ ${ }^{1}$ Division of Hematology and Oncology, Department of Medicine, University of Arizona Cancer Center, \\ University of Arizona, USA \\ ${ }^{2}$ Department of Medicine, University of Arizona, USA \\ ${ }^{3}$ Department of Pathology, University of Arizona, USA
}

Correspondence should be addressed to Soham Puvvada; spuvvada@uacc.arizona.edu

Received 7 September 2014; Revised 17 October 2014; Accepted 17 October 2014; Published 16 November

Academic Editor: Sotirios G. Papageorgiou

Copyright (C) 2014 Josephine Taverna et al. This is an open access article distributed under the Creative Commons Attribution License, which permits unrestricted use, distribution, and reproduction in any medium, provided the original work is properly cited.

\begin{abstract}
A 65-year-old gentleman presented with left groin swelling over the course of two months. Physical exam revealed nontender left inguinal adenopathy, and computed tomography scans detected multiple lymph nodes in the mesenteric, aortocaval, and right common iliac regions. An excisional lymph node biopsy was performed. Pathologic evaluation demonstrated follicular center site which stained positive for PAX5, CD20, CD10, Bcl-2, Bcl-6, and mantle zone cells. These findings demonstrated CCND1 and CD5 positivity, suggesting composite lymphoma comprising follicular lymphoma (FL) with in situ mantle cell lymphoma (MCLIS). FL is known as indolent non-Hodgkin lymphoma; however, the clinical significance of a coexisting MCLIS continues to be elusive, and optimal management of these patients remains largely unknown. This case illustrates the diagnostic and therapeutic challenges of composite lymphomas. This paper also discusses advances in molecular pathogenesis and lymphoma genomics which offer novel insights into these rare diseases.
\end{abstract}

\section{Introduction}

Composite lymphoma (CL) is defined by two or more morphologically and immunophenotypically distinct lymphomas observed within the same anatomic site [1]. Only 6 cases of composite FL and MCL lymphoma have been reported to date (Table 1) [2-7], and FL with coexistent MCLIS cases have only been described in 6 patients (Table 2) [5-9]. The FL component typically appears to be low grade, harbors the $\mathrm{t}(14 ; 18)$ translocation, and stains positive for $\mathrm{Bcl}-2$ on immunohistochemistry (IHC). The MCL component, however, displays a diffuse or in situ mantle-zone growth pattern, harbors the $t(11 ; 14)$ translocation, and expresses CCND1 $[10,11]$. The incidence of CL ranges from 1-4.7\% of total lymphomas and has no gender or ethnic predilection. Here, we add one more case to the rare collection of FL with "in situ" MCL, where such findings are often incidental and associated with indolent clinical course.

\section{Case Presentation}

A 65-year-old male with a history of gastric bypass surgery and left inguinal hernia repair presented with left groin swelling for two months without any other associated symptoms. He initially presented with an enlarged, palpable, nontender left inguinal lymph node measuring $1 \times 1.5 \mathrm{~cm}$. Initial laboratory results, including complete blood count, complete metabolic panel, lactate dehydrogenase, and beta2-microglobulin, were normal. Computed tomography scan detected multiple lymph nodes in the mesenteric, aortocaval, and right common iliac lymph nodes measuring up to $13 \mathrm{~mm}$ in diameter. At the time of surgical evaluation, 
TABLE 1: MCL and FL composite lymphomas.

\begin{tabular}{|c|c|c|c|c|c|c|}
\hline Case number & $\begin{array}{c}\text { Age } \\
\text { Gender }\end{array}$ & Involvement & Immunohistochemistry staining & Treatment & Follow-up & Ref \\
\hline 1 & $66 \mathrm{~F}$ & $\begin{array}{l}\text { Waldeyer ring } \\
\text { Tonsil } \\
\text { Pharyngeal wall } \\
\text { Lingual tonsil } \\
\text { Nasal cavity }\end{array}$ & $\begin{array}{l}\text { MCL: CD5+, CD20+, IgD+, } \\
\text { cyclinD1+, Bcl-2+, CD3- } \\
\text { FL: CD2+, CD10+, Bcl-2+, } \\
\text { Bcl-6+, CD5- }\end{array}$ & Corticosteroid & PET scan every 3-6 months & {$[2]$} \\
\hline 2 & M & Ocular adnexa & NA & NA & Poor prognosis mentioned & {$[3]$} \\
\hline 3 & $84 \mathrm{~F}$ & Spleen & $\begin{array}{l}\text { FL: CD20+, CD23+, Bcl-6+, } \\
\text { CD5-, CD } 43-, \text { Bcl-2- } \\
\text { MCL: cyclinD1+, CD5- }\end{array}$ & $\begin{array}{c}\text { Splenectomy } \\
\text { Patient refused } \\
\text { additional treatment }\end{array}$ & $\begin{array}{l}9 \text { months after } \\
\text { splenectomy, CT scan } \\
\text { showed intra-abdominal } \\
\text { lymphadenopathy and } \\
\text { patient died from unknown } \\
\text { cause } 13 \text { months later }\end{array}$ & {$[4]$} \\
\hline 4 & $70 \mathrm{~F}$ & $\begin{array}{l}\text { Cervical LN } \\
\text { Inguinal LN }\end{array}$ & $\begin{array}{l}\text { CD20+, CD3-, cyclinD1- } \\
50 \% \text { of B-cell expressed CD5 } \\
\text { (MCL) } \\
30 \% \text { of B-cell expressed CD10 } \\
\text { (FL) }\end{array}$ & No chemotherapy & $\begin{array}{l}\text { CT of chest and abdomen } \\
\text { showed no evidence of } \\
\text { lymphadenopathy or } \\
\text { hepatosplenomegaly }\end{array}$ & {$[5]$} \\
\hline 5 & $65 \mathrm{M}$ & Inguinal LN & $\begin{array}{l}\text { FL: CD20+, CD79a+, CD10+, } \\
\text { Bcl-2+, CD5-, CD230, } \\
\text { cyclinD1-, p27+ } \\
\text { MCL: CD20+, CD79a+, CD5+, } \\
\text { CD10-, CD23-, cyclinD1+, p27- } \\
\text { Interfollicular areas mostly CD5+ } \\
\text { showing distinct cylinD1 staining }\end{array}$ & Splenectomy & $\begin{array}{l}\text { MCL caused disease } \\
\text { progression into spleen. } \\
\text { One year after splenectomy, } \\
\text { it achieved stable disease }\end{array}$ & {$[6]$} \\
\hline 6 & $58 \mathrm{~F}$ & $\begin{array}{l}\text { Mesenteric LN } \\
\text { Small bowel }\end{array}$ & $\begin{array}{l}\text { MCL: CD5+, CD20+, CD } 43+ \\
\text { FL: CD10+, CD20+, p27+ }\end{array}$ & $\begin{array}{c}22 \text { cycles of } \\
\text { chemotherapy over } 2 \\
\text { years }\end{array}$ & Complete remission & {$[7]$} \\
\hline
\end{tabular}

TABLE 2: MCL in situ with FL.

\begin{tabular}{|c|c|c|c|c|c|c|c|}
\hline $\begin{array}{l}\text { Case } \\
\text { number }\end{array}$ & Histology & $\begin{array}{l}\text { Immunohistochemistry } \\
\text { flow cytometry }\end{array}$ & $\begin{array}{l}\text { FISH/southern } \\
\text { blot/PCR }\end{array}$ & $\begin{array}{c}\text { Tissue } \\
\text { microdissection }\end{array}$ & $\begin{array}{c}\text { Molecular technique } \\
\text { to determine clonal } \\
\text { relationships }\end{array}$ & $\begin{array}{c}\text { Results } \\
\text { interpretation }\end{array}$ & Ref \\
\hline 1 & $\begin{array}{l}\text { MCL: In situ } \\
\text { FL: LG/G1 }\end{array}$ & $\begin{array}{l}\text { In situ MCL: CD5-; } \\
\text { cyclin D1+; CD23- } \\
\text { FL: CD10+; BCL2+ }\end{array}$ & NA & Not done & Not done & Not known & {$[5]$} \\
\hline 2 & $\begin{array}{l}\text { MCL: In situ } \\
\text { FL: LG/G1 }\end{array}$ & $\begin{array}{l}\text { In situ MCL: CD5+; } \\
\text { cyclin D1+; CD23- } \\
\text { FL: CD10+; BCL2+ }\end{array}$ & $\begin{array}{l}t(11 ; 14)+ \\
t(14 ; 18)+\end{array}$ & Performed & IgH PCR FR1 FR3 JH & $\begin{array}{l}\text { Clonally } \\
\text { related }\end{array}$ & {$[6]$} \\
\hline 3 & $\begin{array}{l}\text { MCL: In situ } \\
\text { FL: LG/G1-2, in } \\
\text { situ }\end{array}$ & $\begin{array}{c}\text { In situ MCL: CD5-; } \\
\text { cyclin D1+; CD23- } \\
\text { FL: CD10+; BCL2- } \\
\text { In situ FL: CD10+; } \\
\text { BCL2+ }\end{array}$ & $\begin{array}{l}t(11 ; 14)+ \\
t(14 ; 18)+\end{array}$ & Performed & $\begin{array}{l}\text { IgH PCR FR2 D1-6 } \\
\text { IgL PCR Vk/Kde }\end{array}$ & $\begin{array}{l}\text { Clonally } \\
\text { related }\end{array}$ & [7] \\
\hline 4 & $\begin{array}{l}\text { MCL: In situ } \\
\text { FL: Stage } 4 \mathrm{~B}\end{array}$ & $\begin{array}{l}\text { In situ MCL: CD5-; } \\
\text { cyclin D1+; CD23- } \\
\text { FL: CD10+; BCL2+ }\end{array}$ & NA & Not done & Not Done & Not known & {$[8]$} \\
\hline 5 & $\begin{array}{l}\text { MCL: In situ } \\
\text { FL: NA }\end{array}$ & $\begin{array}{l}\text { In situ MCL: CD5+; } \\
\text { cyclin D1-; CD23- } \\
\text { FL: CD10+; BCL2+ }\end{array}$ & $\begin{array}{c}\mathrm{t}(14 ; 18)(\mathrm{q} 32 ; \mathrm{q} 21) \\
+ \\
\mathrm{t}(11 ; 14)(\mathrm{q} 13 ; 32)+\end{array}$ & Performed & PCR for IgH & $\begin{array}{l}\text { Clonally } \\
\text { related }\end{array}$ & [9] \\
\hline 6 & $\begin{array}{l}\text { MCL: In situ } \\
\text { FL: NA }\end{array}$ & $\begin{array}{c}\text { In situ MCL: CD5+; } \\
\text { cyclin D1+; CD23 NA } \\
\text { FL: CD10+; BCL2+ }\end{array}$ & $\begin{array}{l}\mathrm{t}(11 ; 14)+ \\
\mathrm{t}(14 ; 18)+\end{array}$ & Performed & PCR for IgH & $\begin{array}{l}\text { Clonally } \\
\text { related }\end{array}$ & [9] \\
\hline
\end{tabular}


the inguinal lymph node had regressed and was difficult to pinpoint by physical exam. He, therefore, underwent excisional biopsy of a mesenteric lymph node visible on the CT scan (Figure 1). The follicular center site stained positive for PAX5, CD20, CD10, Bcl-2, and B-cell lymphoma 6 (Bcl-6), indicating follicular lymphoma. However, CCND1 unexpectedly highlighted CD5 positive mantle zone cells in neoplastic follicles, which suggested a MCLIS (Figure 2) component. FISH analysis demonstrated $35 \%$ of $t(11 ; 14)$ and $65 \%$ of $\mathrm{t}(14 ; 18)$ in tested nuclei that are mutually exclusive. Further workups including bone marrow biopsy and aspirate were unremarkable. Colonoscopy with random biopsies was negative with no evidence of malignancy although esophagogastroduodenoscopy was not feasible due to his recent gastric bypass surgery. The patient has been followed up for 2 years since initial diagnosis of composite lymphoma and is currently under active clinical surveillance without any signs of disease progression.

\section{Discussion}

FL is one of the common non-Hodgkin lymphomas with an estimated incidence of 3.18 cases per 100,000 people in the USA [19]. FL can present with asymptomatic lymphadenopathy and bone marrow involvement; however, extranodal involvement is relatively uncommon [20]. FL is the prototype for indolent lymphomas and has a median overall survival of greater than 10 years with current treatment paradigms [20]. FL arises from follicular germinal centers within lymph nodes, when naïve B-cells undergo somatic hypermutation (SHM) in the $\mathrm{VH}$ region of the immunoglobulin genes during antigen stimulation. Normally, B-cells with lower affinity to antigen undergo apoptosis (negative selection); however, the FL precursors with $\mathrm{t}(14 ; 18)(\mathrm{q} 32 ; \mathrm{q} 21)$ rearrangement are able to survive through negative selection due to constitutive Bcl2 overexpression. During SHM, additional point mutations, deletions, and duplications are introduced in the DNA sequence of $\mathrm{VH}$ region that can contribute to pathogenesis of FL [21].

MCL is an aggressive and relatively rare lymphoma with an annual incidence of approximately 4-8 cases per million in the USA $[22,23] .70 \%$ of MCL cases present with advanced disease characterized by splenomegaly, nodal, and/or extranodal involvements [24, 25]. A small subset of patients may follow an indolent clinical course, although clinical progression warrants early therapeutic intervention $[25,26]$. Morphologically, five cytological variants of MCL have been recognized: classic, small cell, marginal zone-like, pleomorphic, and blastoid. The $\mathrm{t}(11 ; 14)(\mathrm{q} 13 ; 32)$ chromosomal rearrangement is the hallmark of MCL, and it results in overexpression of protooncogene, CCND1 [27].

In situ lymphomas are recognized in the WHO classification of both MCL and FL. They are usually incidental findings in reactive-appearing lymph nodes [28]. In situ mantle cell lymphoma (MCLIS) is characterized by CCND1 positive MCL-like cells restricted to the mantle zone of hyperplastic follicles in reactive lymphoid tissues of healthy individuals [12]. MCLIS is extremely rare with only 22 cases reported to date. It has a heterogeneous clinical presentation with 6 cases demonstrating extranodal disease (i.e., lacrimal glands, nasopharynx, oropharynx, and gastrointestinal tract), 1 case with splenic involvement, and bone marrow involvement in $26 \%$ of reported cases (Table 3 ) $[8,12-18]$. The diagnosis of MCLIS is often made incidentally from biopsies performed during lymphoma workup. Morphologically, the architecture of the lymphoid tissue remains intact and reactive follicles are mainly distributed in the cortical areas. The mantle zones of these follicles are preserved and CCND1 positive cells are often restricted to mantle zones [12].

Most of MCLIS cells can be divided into two groups: CD5-negative and CD5-positive MCLIS. CD5-negative MCLIS can be typically seen in younger patients, where it often presents with nodal involvement and requires no treatment in most cases. On the other hand, CD5-positive MCLIS is associated with older age, extranodal involvement, and other lymphomas. Patients with CD5-positive MCLIS are more likely to require treatment. Interestingly, no difference in survival has been noted between these two groups [15].

The $\mathrm{t}(11 ; 14)$ (q13; q32) rearrangement juxtaposing the protooncogene CCND1 to the immunoglobulin heavy chain (IGH) complex is considered a pivotal event in the development of MCL. This translocation occurs within the bone marrow during pre-B stage differentiation with $\mathrm{V}$ (D) $\mathrm{J}$ recombination of the IGH variable region (IGHV) [10]. It is hypothesized that the naive B-cell carrying $\mathrm{t}(11 ; 14)$ colonizes the mantle zone of the lymphoid follicle, generating an in situ MCL lesion. Two distinct populations of MCLIS tumors have been recently described. SOX11-positive MCLIS tumors reside in the mantle zone of lymphoid follicles, are genetically unstable, and undergo limited IGHV somatic mutations. Alternatively, SOX11-negative MCLIS tumors are genetically stable and arise from naïve B-cells harboring $t(11 ; 14)$ which enter the germinal center and undergo IGHV somatic hypermutations. Carvajal-Cuencia et al. found SOX11 expression in $44 \%$ of 16 cases with MCLIS and hypothesized that MCLIS may represent an early step in MCL lymphomagenesis [12]. One would presuppose that SOX-positive MCLIS and FL are clonally unrelated and mutually exclusive. However, previous studies show that $15-40 \%$ of MCLs carry IGHV hypermutations with a strong bias in the IGHV gene repertoire [29]. Collectively, these results suggest that both lymphomas may originate from the same preneoplastic clone. Unfortunately, depletion of material from confirmatory pathological studies did not permit PCR evaluation for clonality in our patient.

No guidelines have been established for the staging and management of MCLIS. The majority of patients with MCLIS will not develop overt MCL. Therefore, they can be followed up for long periods without treatment [12]. Tumor surveillance with imaging only in the presence of diseaserelated symptoms or organ involvement appears reasonable. MLCIS must be distinguished from mantle cell lymphoma with a mantle zone pattern and overt mantle cell lymphoma because their treatment approaches vary. Accordingly, staging workup to exclude other sites of involvement or rule out the coexistence of an overt lymphoma is recommended. When FL and MCLIS are reported simultaneously, the dominant lymphoma should be treated when patient requires treatment [30]. Our patient does not meet any indications for 


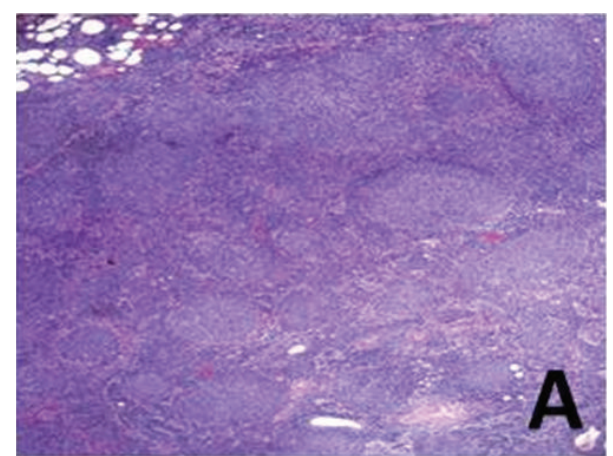

(a)



(c)

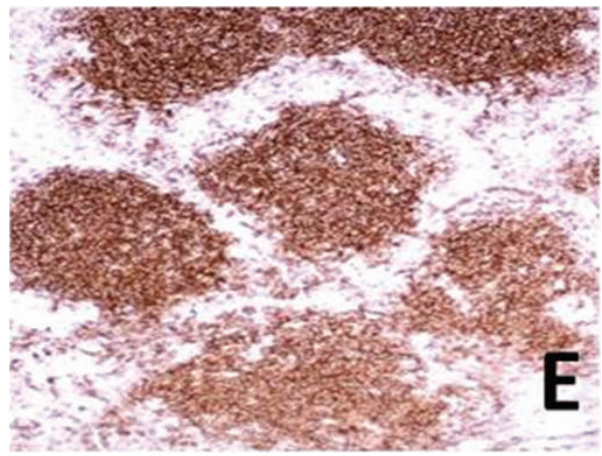

(e)

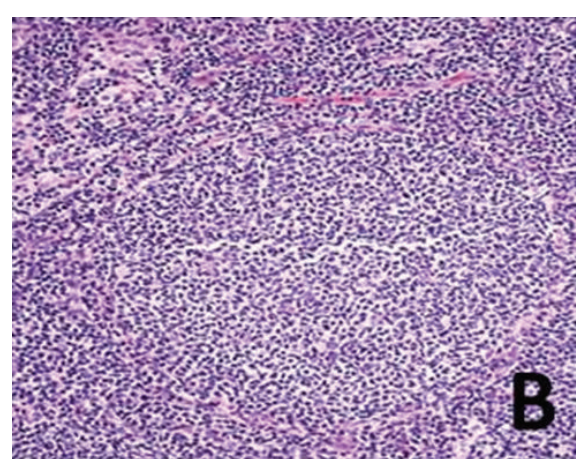

(b)

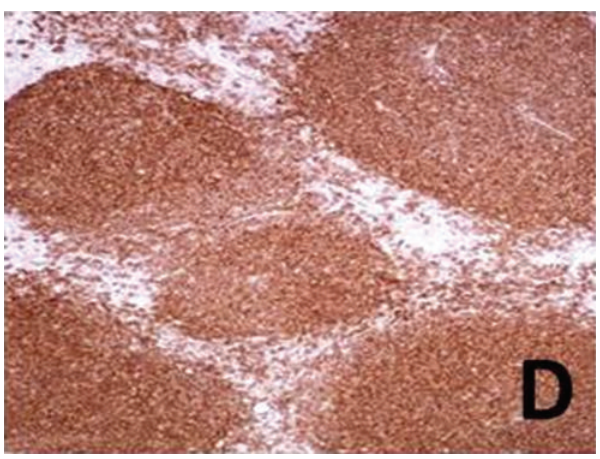

(d)



(f)



(g)

Figure 1: H \& E and immunohistochemical staining of follicular components. Hematoxylin and eosin stained sections showed numerous neoplastic follicles occupying almost the entire lymph node, effacing the normal nodal architecture extending from the cortex to the hilum, and invading beyond the capsule ((a) $4 \mathrm{x})$. The neoplastic follicles consist of small centrocytes with ovoid shape, small angulated nuclei, clumped chromatin, and inconspicuous or absent nucleoli. Rare intermixed centroblasts are seen ((b) 20x and (c) 40xs). Immunohistochemical staining revealed the germinal center cells expressing the pan B-cell marker CD20 ((d) 10x) in addition to germinal center-associated markers CD10 ((e) 10x), BCL-6 ((f) 10x), and BCL-2 ((g) 10x). The collective histologic and immunophenotype findings indicated a follicular lymphoma, grade 1 of 3 . 









(a)

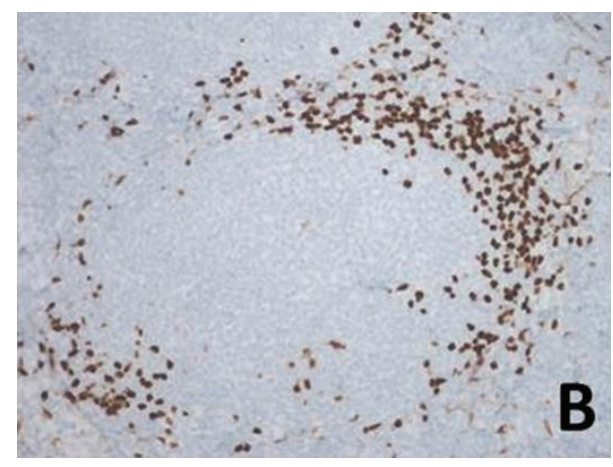

(b)

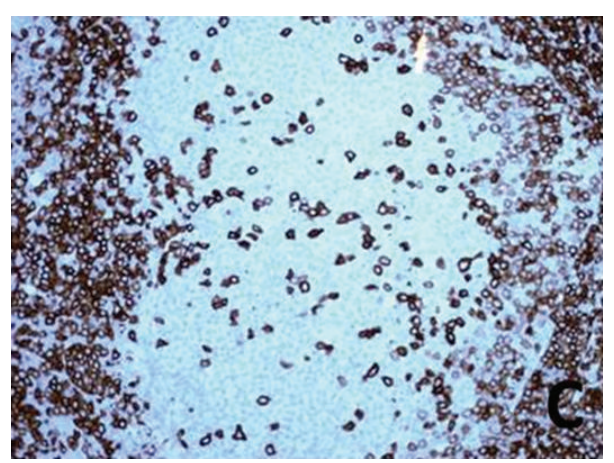

(c)

FIGURE 2: Immunohistochemical staining of in situ mantle cell lymphoma components. Cyclin D1 immunohistochemistry revealed a peripheral rim of positive cells within the mantle zones of the majority of the neoplastic secondary follicles ((a) 4x and (b) 20x). These cells appeared to show dim coexpression of CD5 ((c) 20x).

treatment, and he has been under active clinical surveillance for 2 years without any signs of disease progression. If there is any evidence of disease progression, we plan to repeat complete staging work-up including a bone marrow and lymph node biopsy with PCR analysis.

\section{Conclusion}

The significance of MCLIS still remains obscure. At this moment, it is unknown whether MCLIS represents true precursor lesions that will progress to an overt lymphoma or are incidental findings with a low chance of progression. Composite lymphoma with FL and MCLIS can pose diagnostic and therapeutic challenges. However, with new advances in molecular pathology and lymphoma genomics, we have more opportunities to investigate these rare diseases and gain novel insights into their biology in order to benefit the management of affected patients.

\section{Consent}

Written informed consent was obtained from the patient for publication of this case report and any accompanying images. A copy of the written consent is available for review by the Editor-in-Chief of this journal.

\section{Conflict of Interests}

The authors declare that there is no conflict of interests regarding the publishing of this paper.

\section{Authors' Contribution}

Josephine Taverna and Anju Nair contributed equally to this work and share first authorship.

\section{References}

[1] H. Kim, "Composite lymphoma and related disorders," American Journal of Clinical Pathology, vol. 99, no. 4, pp. 445-451, 1993.

[2] R. B. Ilgenfritz, A. le Tourneau, M. Arborio et al., "Composite mantle cell and follicular lymphoma. A case report," Human Pathology, vol. 40, no. 2, pp. 259-263, 2009.

[3] A. Looi, R. D. Gascoyne, M. Chhanabhai, J. M. Connors, J. Rootman, and V. A. White, "Mantle cell lymphoma in the ocular adnexal region," Ophthalmology, vol. 112, no. 1, pp. 114-119, 2005.

[4] M. R. Roullet, D. Martinez, L. Ma et al., "Coexisting follicular and mantle cell lymphoma with each having an in situ component: a novel, curious, and complex consultation case of coincidental, composite, colonizing lymphoma," American Journal of Clinical Pathology, vol. 133, no. 4, pp. 584-591, 2010. 
[5] P. Tsang, L. Pan, E. Cesarman, J. Tepler, and D. M. Knowles, "A distinctive composite lymphoma consisting of clonally related mantle cell lymphoma and follicle center cell lymphoma," Human Pathology, vol. 30, no. 8, pp. 988-992, 1999.

[6] A. Zamò, R. Zanotti, M. Lestani et al., "Molecular characterization of composite mantle cell and follicular lymphoma," Virchows Archiv, vol. 448, no. 5, pp. 639-643, 2006.

[7] F. Fend, L. Quintanilla-Martinez, S. Kumar et al., "Composite low grade B-cell lymphomas with two immunophenotypically distinct cell populations are true biclonal lymphomas: a molecular analysis using laser capture microdissection," American Journal of Pathology, vol. 154, no. 6, pp. 1857-1866, 1999.

[8] N. Aqel, F. Barker, K. Patel, and K. N. Naresh, "In-situ mantle cell lymphoma-a report of two cases," Histopathology, vol. 52, no. 2, pp. 256-260, 2008.

[9] A. Matsuoka, T. Tsushima, M. Tanibuchi et al., "Composite lymphoma cosisting of mantle cell lymphoma and follicular lymphoma," Rinshō ketsueki, vol. 54, no. 11, pp. 2056-2061, 2013.

[10] P. Jares, D. Colomer, and E. Campo, "Genetic and molecular pathogenesis of mantle cell lymphoma: perspectives for new targeted therapeutics," Nature Reviews Cancer, vol. 7, no. 10, pp. 750-762, 2007.

[11] P. Jares, D. Colomer, and E. Campo, "Molecular pathogenesis of mantle cell lymphoma," The Journal of Clinical Investigation, vol. 122, no. 10, pp. 3416-3423, 2012.

[12] A. Carvajal-Cuenca, L. F. Sua, N. M. Silva et al., "In situ mantle cell lymphoma: clinical implications of an incidental finding with indolent clinical behavior," Haematologica, vol. 97, no. 2, pp. 270-278, 2012.

[13] A. Bassarova, A. Tierens, G. F. Lauritzsen, A. Fosså, and J. Delabie, "Mantle cell lymphoma with partial involvement of the mantle zone: an early infiltration pattern of mantle cell lymphoma?” Virchows Archiv, vol. 453, no. 4, pp. 407-411, 2008.

[14] B. Espinet, F. Solé, C. Pedro et al., "Clonal proliferation of cyclin D1-positive mantle lymphocytes in an asymptomatic patient: an early-stage event in the development or an indolent form of a mantle cell lymphoma?" Human Pathology, vol. 36, no. 11, pp. 1232-1237, 2005.

[15] P. Hsu, T. Yang, S. Sheikh-Fayyaz et al., "Mantle cell lymphoma with in situ or mantle zone growth pattern: a study of five cases and review of literature," International Journal of Clinical and Experimental Pathology, vol. 7, no. 3, pp. 1042-1050, 2014.

[16] L. Nodit, D. W. Bahler, S. A. Jacobs, J. Locker, and S. H. Swerdlow, "Indolent mantle cell lymphoma with nodal involvement and mutated immunoglobulin heavy chain genes," Human Pathology, vol. 34, no. 10, pp. 1030-1034, 2003.

[17] S. J. Rodig, B. M. Healey, G. S. Pinkus, F. C. Kuo, P. D. Cin, and J. L. Kutok, "Mantle cell lymphoma arising within primary nodal marginal zone lymphoma: a unique presentation of two uncommon B-cell lymphoproliferative disorders," Cancer Genetics and Cytogenetics, vol. 171, no. 1, pp. 44-51, 2006.

[18] Y. Liu, P. Li, Y. Guo, L. Fan, L. Wang, and J. Zhu, "A unique composite follicular lymphoma and mantle cell lymphoma with a mixed cell pattern and aggressive course," American Journal of Clinical Pathology, vol. 141, pp. 737-741, 2014.

[19] L. M. Morton, S. S. Wang, S. S. Devesa, P. Hartge, D. D. Weisenburger, and M. S. Linet, "Lymphoma incidence patterns by WHO subtype in the United States, 1992-2001," Blood, vol. 107, no. 1, pp. 265-276, 2006.

[20] A. Freedman, "Follicular lymphoma: 2011 update on diagnosis and management," American Journal of Hematology, vol. 86, no. 9, pp. 768-775, 2011.
[21] R. Kridel, L. H. Sehn, and R. D. Gascoyne, "Pathogenesis of follicular lymphoma," The Journal of Clinical Investigation, vol. 122, no. 10, pp. 3424-3431, 2012.

[22] J. O. Armitage, "A clinical evaluation of the International Lymphoma Study Group classification of non-Hodgkin's lymphoma," Blood, vol. 89, no. 11, pp. 3909-3918, 1997.

[23] Y. Zhou, H. Wang, W. Fang et al., "Incidence trends of mantle cell lymphoma in the United States between 1992 and 2004," Cancer, vol. 113, no. 4, pp. 791-798, 2008.

[24] H. Samaha, C. Dumontet, N. Ketterer et al., "Mantle cell lymphoma: a retrospective study of 121 cases," Leukemia, vol. 12, no. 8, pp. 1281-1287, 1998.

[25] J. M. Vose, "Mantle cell lymphoma: 2013 update on diagnosis, risk-stratification, and clinical management," American Journal of Hematology, vol. 88, no. 12, pp. 1082-1088, 2013.

[26] P. Martin, A. Chadburn, P. Christos et al., "Outcome of deferred initial therapy in mantle-cell lymphoma," Journal of Clinical Oncology, vol. 27, no. 8, pp. 1209-1213, 2009.

[27] F. Bertoni and M. Ponzoni, "The cellular origin of mantle cell lymphoma," International Journal of Biochemistry and Cell Biology, vol. 39, no. 10, pp. 1747-1753, 2007.

[28] S. H. Swerdlow, WHO Classification of Tumors of Hematopoietic and Lymphoid Tissues, IARC Press, Lyon, France, 4th edition, 2008.

[29] S. Wang, A. Tzankov, Z. Y. Xu-Monette et al., "Clonally related composite follicular lymphoma and mantle cell lymphoma with clinicopathologic features and biological implications," Human Pathology, vol. 44, no. 12, pp. 2658-2667, 2013.

[30] A. Carbone and A. Santoro, "How I treat: diagnosing and managing "in situ" lymphoma," Blood, vol. 117, no. 15, pp. 39543960, 2011. 


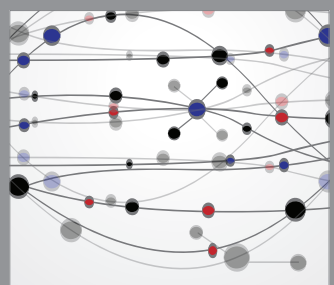

The Scientific World Journal




Gastroenterology

Research and Practice


\section{Hindawi}

Submit your manuscripts at

http://www.hindawi.com
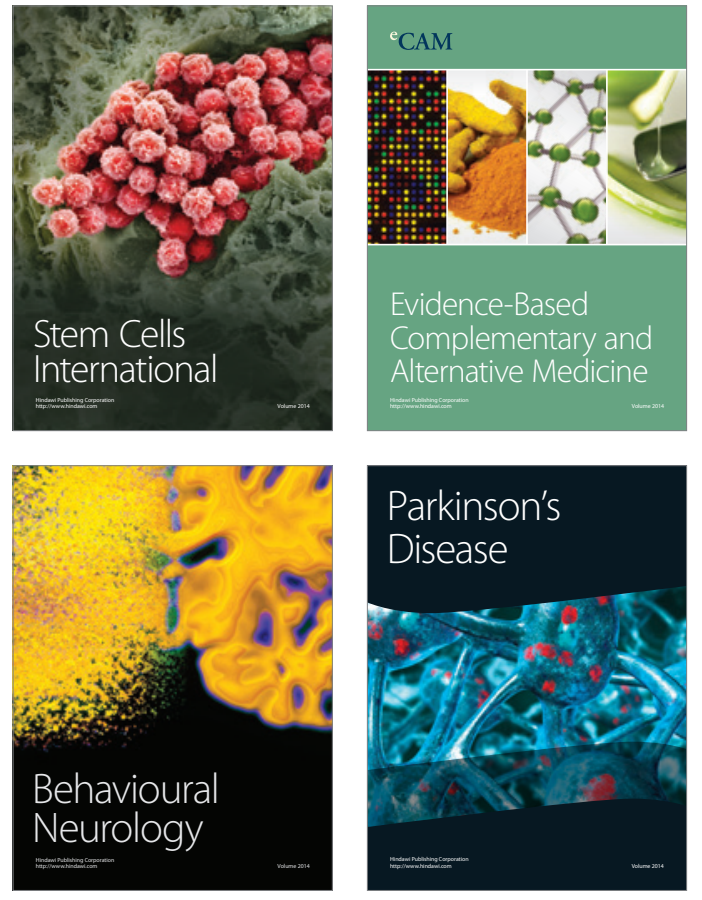
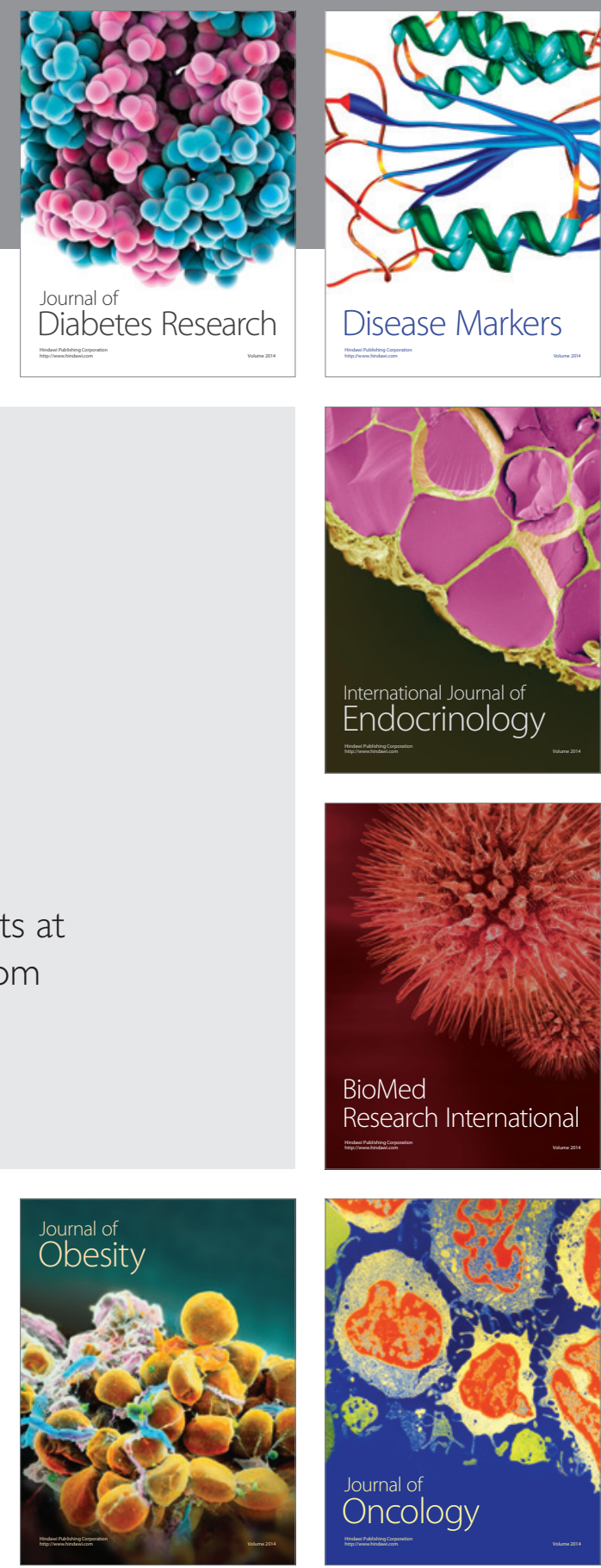

Disease Markers
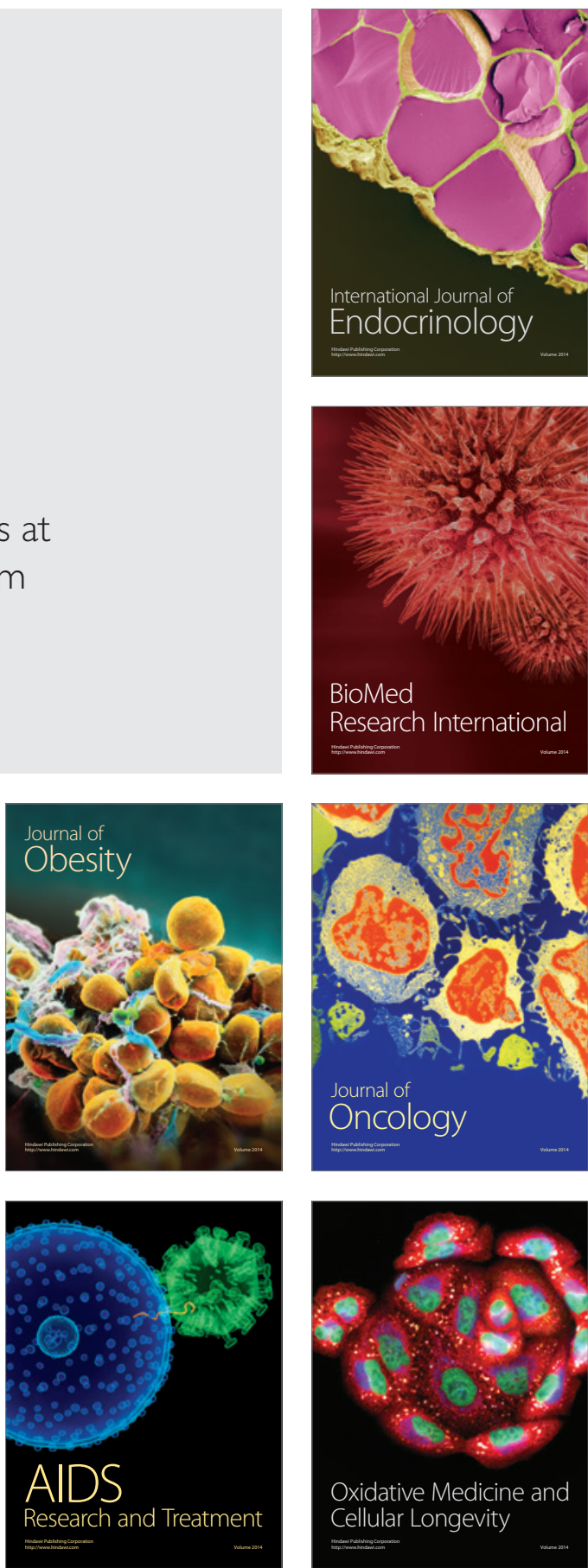